\title{
Funding Sources for Research and Education Projects, ICT and Science Researchers in Europe and USA
}

\author{
Arbër Beshiri' ${ }^{1}$, Samedin Krrabaj ${ }^{1}$, Dorëlir Beshiri² \\ ${ }^{1}$ Faculty of Computer Science, University “Ukshin Hoti”, Prizren, Kosovo \\ ${ }^{2}$ Departments of Management and Informatics, AAB College, Prishtina, Kosovo \\ Email: arber.beshiri@uni-prizren.com,samedin.krrabaj@uni-prizren.com, beshiridorelir@gmail.com
}

How to cite this paper: Beshiri, A., Krrabaj, S. and Beshiri, D. (2020) Funding Sources for Research and Education Projects, ICT and Science Researchers in Europe and USA. Open Access Library Journal, 7: e6058. https://doi.org/10.4236/oalib.1106058

Received: January 8, 2020

Accepted: March 10, 2020

Published: March 13, 2020

Copyright $\odot 2020$ by author(s) and Open Access Library Inc.

This work is licensed under the Creative Commons Attribution International License (CC BY 4.0).

http://creativecommons.org/licenses/by/4.0/

\section{(c) (i) Open Access}

\begin{abstract}
Funds are provided in different ways to higher education institutions. They are made possible through private or public actors. Usually they are distributed as a form of tuitions, gifts, grants, research donations, etc. Funds are given for the purpose of empowering and promoting the activities of universities, faculties and their staff. When universities show high performance in teaching, research and innovation, they are considered potential for obtaining funds from the agencies that distribute them. In this paper is discussed about different European and American funding sources for ICT research, education, innovation and researchers. Hereby are giving details about the opportunities that these organizations (agencies) offer specific programs that are dedicated for the above mentioned purposes. Despite of details that are given for each fund and programs, also are given results about the funds and their programs according some indicators that they are presented in the part of results and discussions, these funds are an excellent opportunity for researchers to develop their innovative and research ideas and to realize them through support of specific programs of these funds.
\end{abstract}

\section{Subject Areas}

Information and Communication Technologies, Computer Science, Education, Management and Informatics.

\section{Keywords}

Founding Sources, Education, Innovation, Research, ICT Researchers

\section{Introduction}

Funds for higher education institutions are available in different forms from 
private and public actors. They are awarded as tuition, grants, research contracts and gifts. Funds are usually provided as support to students, faculties, staff and universities. They promote (foster) many activities of universities, faculty and staff. Higher funding levels are provided by agencies when universities offer high quality in teaching and research and promote educational and organizational innovations [1].

They are provided with various amounts for education, research and innovation. Funds are provided by the European Union (most of its states) and USA. In the following, the funds of the agencies (organizations) of the aforementioned countries will be discussed. These funds motivate (encourage) the participants and working groups to work in science, research, information technology and education by supporting them in career, personal development and other aspects of their wellness and community.

\section{Funding Sources}

\subsection{Horizon 2020}

This is the biggest program of the European Union (EU) for research and innovation, though of which it offers approximately 80 billiard Euros during seven years (2014-2020) for the private investments and the community goods. It offers financial supports for breakthroughs, innovation and ideas tested in laboratories and applicable in the market. This financial instrument is implemented by the Innovation Union as an initiative under the Europe 2020 that it has aimed for ensuring Europe's global competitiveness [2].

Horizon 2020 is an initiative created by the European leaders and members of the European Parliament as a financial tool for economic growth and job creation. The European Parliament members and leaders have concluded that research is an investment for the future and should be financially supported to enable individuals and groups to develop smart tools, sustainable for inclusive economic growth and job creation. The EU funds for research and innovation activities are distributed by the Seven EU programs [2].

The main program is Horizon 2020 (with the 8th Framework for Research and Innovation) through which funds are provided for such activities. Funds for regional levels, such as the European Structural and Investment Funds can be used for research purposes and innovations at local levels [2]. According to Vincent Reillon [3], a member of the European Research Service under the European Parliament, the EU funds for research and innovation activities reaches more than 120 million euros for the period 2014 to 2020 [3].

Horizon 2020, in terms of research and innovation is helping to achieve excellent science, industrial leadership and handling social challenges. Through this program the EU has purposed to provide world-class science in Europe, to remove innovation barriers and to enable collaboration between public and private sector in providing novelties in innovation. COSME, Erasmus+, the Health program, the Life program and the Connecting Europe Facility are five programs that are related to Horizon 2020. They have influence in research and in- 
novation activities [3].

The European Research Area will be developed and completed further thought the EU Framework Program for research and innovation. The EU purpose is to break barriers and to create a single market for education, research and innovation [2]. Under the Horizon 2020 is the Excellence of Science fund.

It contains several sub-funds such as:

- European Research Council (ERC) ${ }^{1}$, which enables individual and teams' researchers to do research with promising results in science over EU being competitive in the research aspects. This program offers grants for research projectsfor excellence in science, young researchers, independent excellent researchers, senior research leaders, innovators who have potential of research results for innovation projects. For grants of this program, applicants may apply to any field of research, including social sciences and humanities. The targeting groups of this program are independent researchers of any country of the world; educational, public and private institutions; research centers, NGOs, etc. Research must be done in one of the $28 \mathrm{EU}$ or partner countries. This program is supported and funded by the EU [4].

- Future and emerging technologies ${ }^{2}$ which enable collaborative research to increase research capacities in advanced innovations in Europe and to be open to new fields and different paradigms of innovation. This program is considered as a boost for scientific collaboration in all disciplines; especially for "high-risk ideas" in emergency areas which will enable accelerated the development of promising science and technology fields. Through it will be possible the structuring of scientific communities across the EU. This program offers funds for research, education and innovation projects, emerging topics and development of new materials for the future, scientific and technological projects. Researchers can do research on emerging technologies for future challenges such as arts and sciences, biotechnologies, data analysis, global system science, green technologies, medical and neuro-technologies, nanotechnologies, quantum technologies, robotics and technologies with materials. Target groups are academic institutions, universities, research centers, NGOs, SMEs of EU and other beneficiary countries (Figure 1). This program is funded by the EU under Horizon 2020 [4].

- Marie Skłodowska-Curie Actions ${ }^{3}$. This program offers funds for research, training and innovation. It offers researchers' opportunities for career development and knowledge exchange through mobility in all disciplines. Through this program are offering grants for projects in research and education, conferences, workshops and research infrastructure. Grants are given for all disciplines, while the targeting groups are: public and private universities, research institutions, NGOs, SMEs of EU, independent researchers, non-academic organizations, etc. This program is funded and supported by the EU under the Horizon 2020 [4].

${ }^{1}$ This program is available at: http://ec.europa.eu/programmes/horizon2020/node/3.

${ }^{2}$ This program is available at: http://ec.europa.eu/programmes/horizon2020/node/94s.

${ }^{3}$ This program is available at: http://ec.europa.eu/programmes/horizon2020/node/8. 


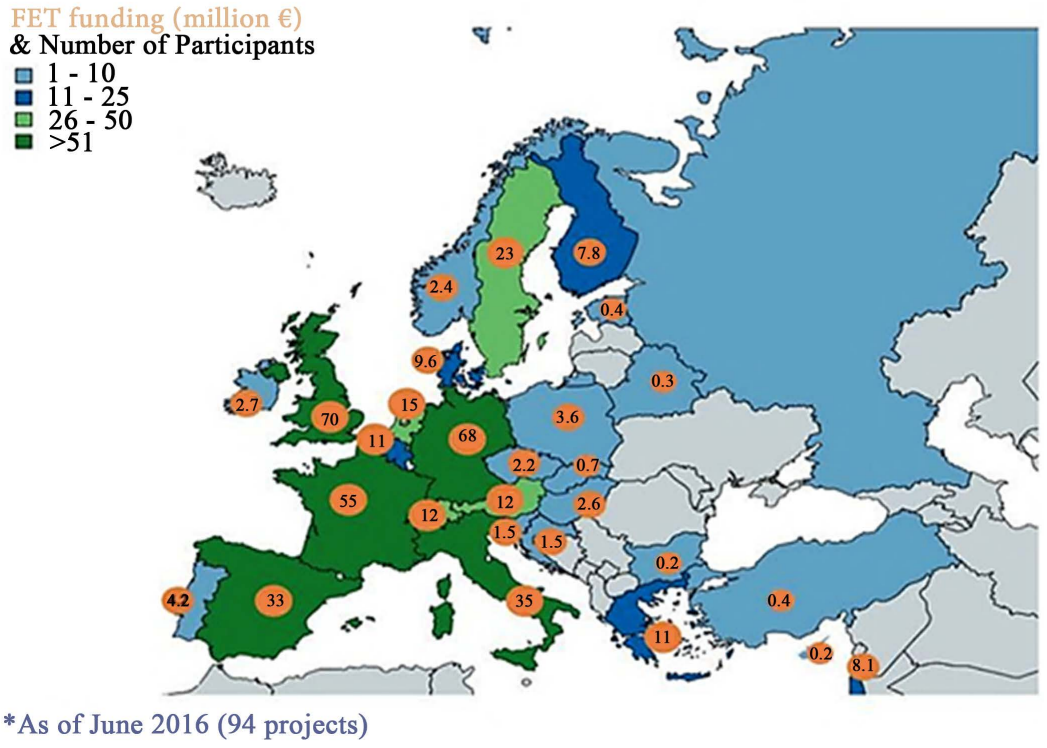

Figure 1. Participating and beneficiary countries of FET funding ${ }^{4}$.

- Research infrastructure ${ }^{5}$ is mainly dedicated to e-infrastructure and it has purpose to develop European research infrastructure up to 2020 and further. EU though this program have aimed to stimulate the innovation potential and human capital by fulfilling it though its policy and in cooperation with its member states and partners. Through this program are offering grants for projects in research, education, e-infrastructure, workshops, incubators and research infrastructure. Grants are given for all disciplines, while the targeting groups are: universities, research institutions, NGOs, SMEs of EU, independent researchers, industries, innovative organizations, etc. This program is supported by the EU [4].

\subsection{Europlan UK}

It is a European foundation that offers training, support and consultancy for organizations that wish to increase their participation in the European projects. Europlan UK provides great opportunities for access by the European institutions. Despite it is registered and operating in London, it has also a strong presence in Brussels. Europlan UK assists organizations in the Balkan region, and it has also increased its activities in Eastern Europe and Russia [5].

It offers these services:

1) It assists in identifying opportunities for participation in the European projects (including training and assistance in drafting project proposals, identifying appropriate partners and informing clients with the EU assistance program which is based on grants for such purposes).

${ }^{4}$ This is available at:

https://ec.europa.eu/programmes/horizon2020/en/news/infographic-participation-horizon-2020-fet -projects.

${ }^{5}$ This program is available at: http://ec.europa.eu/programmes/horizon2020/node/58. 
2) It provides opportunities and contribution in technical and strategic studies (especially in ICT and space industries).

The specialized staff under the Europlan UK provides opportunities for skills in research and development, innovation, regional development and international cooperation. Most of the Europlan UK experts have worked with the European Commission or they have been engaged as evaluators or participants in projects.

The Europlan UK acts as an efficient and effective unit with competitive price and overall expenses it always tries to keep at minimum values by maintaining high standards. It assists various organizations in the research and innovation for specific projects that they are supported by the European Commission [5].

The Europlan UK supports ICT companies in testing, deployment and commercialization of ICT products. It also helps them in the evaluation and return feedback on ICT projects during the processing and software development phases, organization and deployment the product at the European level, and managing innovation from strategies for the final product. Through its laboratories enable research activities with a focus on applied and multidisciplinary research in ICT and social sciences. The Europlan UK regularly makes monitoring of tenders and calls of the financial agencies [5].

It monitors funds:

- Horizon $2020^{6}$,

- Seventh Framework Program RTD (FP7)

- CIP ICT PSP-ICT Policy Support Program ${ }^{8}$,

- CIP IEE-Intelligent Energy Europe Program ${ }^{9}$ and

- CIP EIP-Entrepreneurship and Innovation Program ${ }^{10}$.

\subsection{South East Europe-Transnational Cooperation Program}

This program has aimed to develop a transnational partnership with strategic importance. The program enables the improvement of territorial, economic and social processes. Cohesion, stability and competitive ability in the region are elements supported by this program. The South East Europe (SEE) program tries to provide high-performance, project-focused on results with strategic elements and relevant aspects. The best promotion of integration between member states is supported by the SEE program. It also helps potential candidate countries and

${ }^{6}$ This fund is available at:

https://ec.europa.eu/research/participants/portal/desktop/en/opportunities/index.html.

${ }^{7}$ This fund is available at:

https:/ec.europa.eu/research/participants/portal/desktop/en/opportunities/fp7/index.html\#c,calls= Catego-

ry/t/CALL FOR TENDERS/0/1/0\&Category/t/CALL_FOR PROPOSALS/1/1/0\&Callidentifier.Stat us/t/OPEN/1/1/0\&CallIdentifier.Status/t/CLOSED/0/1/0\&Callidentifier.Status/t/FORTHCOMING/ $\underline{0 / 1 / 0}$.

${ }^{8}$ This fund is available at:

http://ec.europa.eu/information_society/activities/ict_psp/participating/calls/index_en.htm.

${ }^{9}$ This fund is available at: http://ec.europa.eu/cip/iee/index en.htm.

${ }^{10} \mathrm{This}$ fund is available at: $\mathrm{http}: / /$ ec.europa.eu/cip/eip/access-finance/index en.htm. 
their neighboring countries. The essential part of this program is regional cooperation regardless different integration stages of different countries [6].

The Transnational Cooperation program in the territory of Europe focuses on providing sustainable and balanced development. It has purpose to take care of the development and territorial integration within the field of cooperation. The Transnational Cooperation program concentrates on priority areas such as: innovation, environment and sustainable urban development. This program distinguishes from the SEE program only in the number of participating countries where it consists of 16 participating countries. The large number of participating countries and their diversity has made this program to be considered the largest in the cooperation area [6].

"In addition, the SEE Transnational Cooperation Program will actively seek the full participation of non-Member States in the program area benefitting from the external Pre-Accession Assistance and the European Neighborhood Policy funding.

The program area is located at the South Eastern edge of the Union, where several accession candidate countries and potential candidate countries as well as third countries engaged in the EU partnership framework are concentrated, thus going far beyond the external borders of the EU" [6].

The specific objectives of the SEE Transnational Cooperation Program are given as follows:

1) The program helps in innovation, enterprise, economic and social information by concertizing cooperation through visible actions and outcomes.

2) Despite attractive elements, this program enables sustainable development, knowledge access and qualitative environment in regions and cities through integration approach and specific cooperation by visible actions and outcomes.

3) This program takes care of integration through the capacity balancing on all levels for territorial cooperation [6].

The specific objectives of the program are pursued through the Priority Axes which contribute in the different way to the specific objectives of the program:

- "Priority Axis 1: Facilitation of innovation and entrepreneurship.

- Priority Axis 2: Protection and improvement of the environment.

- Priority Axis 3: Improvement of the accessibility.

- Priority Axis 4: Development of transnational synergies for sustainable growth areas" [6].

In the following, only the Priority Axis 1 will be discussed, which relates to innovation, facilitation and entrepreneurship. Competition and innovation have always been a theme of discussion on the SEE regional development policies. The capitals have been adapted with such elements and new challenges. Some of them are attempting to reorient themselves by finding the right strategy for opportunities in the global marketplace. The First Priority Axis (FPA) targets innovation, entrepreneurship and knowledge in the economy. It focuses on integration and economic relations in the field of cooperation [6].

The FPA objectives are trying to achieve through the Area of Intervention 
(AoI):

- AoI 1.1.: For specific areas to develop technology and innovation networks.

- AoI 1.2.: For the innovative entrepreneurship to create an adequate environment.

- AoI 1.3.: Strengthening the framework conditions and opening the way for innovation [6].

The European Commission, the EU Council and the EU Parliament in 2013 under the EU Cohesion policy package have agreed to invest 325, 15 billion Euros in support of research, smart, innovation, sustainability and inclusive growth in Europe over the years 2014-2020. This fund was devoted to three new programs to the SEE Program for the next seven years [6]. This fund is dedicated to the three succeed programs of the SEE Program for the next seven years. These programs are: Adriatic Ionian (ADRION) ${ }^{11}$, Balkan-Mediterranean ${ }^{12}$ and Danube Transnational Program ${ }^{13}$. Through these programs innovation projects are supported. The above mentioned programs also support research projects. The supporting indicators provided by these programs will be mentioned in the section of the classification funds (programs) for research, innovation and education.

\subsection{COST}

It is a European framework that supports international cooperation between researchers, engineers and scholars all over Europe. This program provides opportunities for joint development ideas and initiatives in the field of science and technology, social sciences and humanities through the pan-European network for nationalities established for research activities. Under the intergovernmental framework for cooperation in science and technology, since 1971, COST has contributed to the development and closures the gaps in science, politics and society in Europe and beyond. It is considered as a precursor of advanced multidisciplinary research and plays an important role in building the European Research Area (ERA) [7].

COST predicts and fulfills the activities under the EU Framework Program by becoming interrelationship between the scientific communities of countries. This program contributes to increase mobility between researchers across Europe and it promotes the scientific persuasion. This organization has been structured in nine domains of science and technology that they are merged into a single organization in order to be entirely open and to create access through a single scientific committee. By founding the scientific committee, the evaluation form and selection has been renovated in order to identify progressive ideas and to favor interdisciplinary and multidisciplinary projects [7].

${ }^{11}$ This program is available at:

http://www.adrioninterreg.eu/index.php/about-program/adrion-priority-axis/fostering-regional-inn ovation/.

${ }^{12}$ This program is available at: http://www.interreg-balkanmed.eu/.

${ }^{13}$ This program is available at: http://www.interreg-danube.eu/. 
The COST program extends to 36 COST member states and other collaborative countries that it enables researchers and scientists to participate in science and technology through networks called COST Actions by submitting a proposal for a new COST Action, bringing together existing COST Actions or becoming an external expert of a COST. Participants in COST may be from universities, research centers, private and public organizations from 36 COST member countries and cooperating states. They can participate in the field of science and technology through original and innovative ideas. The COST member states, which participate in Actions, they also constitute average of the COST Actions budget [7].

Horizon 2020-EU Framework Program for Research and Innovation is a sponsor of the COST. The COST Actions are considered as a flexible, effective and efficient instrument for scholars, engineers and researchers. They can coordinate and cooperate among themselves through the research activities funded by the COST Actions. Researchers across Europe can develop their joint ideas for specific areas of science and technology. These joint ideas for specific areas of science and technology are supported by the COST Actions [7].

Through the COST Actions are providing funds for science and technology, researchers and stakeholders for 4 years. COST supports activities such as workshops, conferences, trainings, short-term scientific activities, etc. Individual researches are not funded by COST. It supports research topics in terms of high risk, innovation and emergency; although no research priority is determined by COST. Collaboration in new research projects can lead to new Actions and in this way it increases the networking potential of these consortiums [7].

The research activities in science and technology for peaceful purposes and in the public interest are covered by the COST Actions. Each COST Action contains elements like objective, purpose and results. These elements are described in the Memorandum of Understanding and they are accepted at least seven COST member states and participants. Once the themes, objectives and work organization are proposed, then the researchers choose their themes. Action's Management Committees is getting by these elements. All researchers, scholars and engineers may be the COST Actions members' regardless gender, career or career stages. This is considered a platform that coordinates the national research funds through the networking tools and simple rules. The future of this platform is oriented to the generations of young researchers [7]!

\subsection{Erasmus+}

It is a European Union program (funding) that supports education, training, youth and sport within Europe. Erasmus $+{ }^{14}$ has the budget of 14.7 billion Euros and it offers opportunities for over 4 million Europeans to study, train, receive experience and contribute as a volunteer. It provides not only opportunities for

${ }^{14}$ Erasmus + is available at:

http://ec.europa.eu/programmes/erasmus-plus/resources/documents/erasmus-general-factsheet_en. This program is available at: http://www.interreg-balkanmed.eu/. 
students, but also for individuals and organizations through the Seven Prior Programs. Funding details, register criteria, etc. are provided through the Erasmus+ Program Guide ${ }^{15}$. Through an indicative founding guide ${ }^{16}$ are shown funding options in the aforementioned program for different Actions. Erasmus + provides opportunities (knowledge and experience) for people of all ages. It helps in development and distribution knowledge and experiences in institutions and organizations of various countries [8].

Erasmus + offers opportunities for different organizations, such as universities, other educational, training and research institutions, think tanks and private businesses. The objective and purpose of Erasmus + is to contribute to the Europe 2020 strategy for social, employment and inclusive purposes, with particular emphasis on the EU's strategic education and training framework [8]. The purpose of Erasmus + is to promote sustainable development for its partners in higher education and to contribute the objectives' fulfillment for the EU Youth Strategy ${ }^{17}$.

Erasmus + addresses some specific issues:

- The opportunity to reduce unemployment, especially in the category of young people.

- It promotes adult learning by offering new skills and those required by employment markets.

- It encourages young people to take part in educational issues and trainings on European democracy.

- It provides support for innovation ${ }^{18}$, cooperation ${ }^{19}$, andreforms ${ }^{20}$.

- It contributes to the reduction of young's early leaving school.

- It promotes cooperation and mobility with EU partner countries [8].

The Erasmus + Projects Platform ${ }^{21}$ provides information about funding initiatives of the program, best practices, and success stories in education, training, youth and sport [8]. Erasmus + consists of seven programs as follows:

- Life Long Program (higher education),

- Leonardo da Vinci (vocational training),

- Comenius and eTwinning (school education),

- Grundtvig (adult education) and

- Youth in Action [9].

It includes several other international cooperation programs in various fields, including education and research, such as:

\footnotetext{
${ }^{15}$ Erasmus+ Program Guide is available at: http://ec.europa.eu/programmes/erasmus-plus/resources/programme-guide en. ${ }^{16}$ The indicative founding guide is available at: http://ec.europa.eu/programmes/erasmus-plus/sites/erasmusplus/files/files/resources/eplus-int-he-f unding-2017 en.pdf.

${ }^{17}$ The EU Youth Strategy is available at: https://ec.europa.eu/youth/policy/youth-strategy en.

${ }^{18} \mathrm{http}: / /$ ec.europa.eu/education/policy/strategic-framework/education-technology_en.

${ }^{19} \mathrm{http} / / /$ ec.europa.eu/education/policy/higher-education/bologna-process_en.

${ }^{20} \mathrm{http}: / /$ eur-lex.europa.eu/legal-content/EN/TXT/?qid=1389776578033\&uri=CELEX:52012DC0669.

${ }^{21}$ The Erasmus + Projects Platform is available at:

http://ec.europa.eu/programmes/erasmus-plus/projects/eplus-projects-compendium/.
} 
- Erasmus Mundus,

- Tempus,

- Alfa,

- Edulink (for cooperation with developed countries) [9].

The supporting indicators provided by these programs will be highlighted in the results part of the funds' programs for research, innovation and education.

\subsection{Western Balkan Countries}

It is a program that provides funds for education, research and innovation. This program consists of three platforms: WBC-RTI.info ${ }^{22}$, WBC-INCO.net and Danube-INCO.net. WBC-RTI.info is a platform (source) that provides information about research, technology and innovation for the Western Balkan countries (WBC) built on the WBC-INCO.net platform. It includes relevant information and various databases. This platform is supported by the Austrian Federal Ministry of Science, Research and Economy. After registering on this platform, we can publish announcements about our events, project documents, relevant information about funding opportunities, cooperation, scholarships, etc. This platform is also funded by the $7^{\text {th }}$ Framework Program for Research and Technological Development ${ }^{23}$.

The basic objectives of this information platform:

- To support the distribution of information through its website by publishing a monthly bulletin and information via social media (Facebook, LinkedIn and Twitter).

- To provide analytic support for research, technology and innovation topics through evaluation, statistics, research funds, etc.

- It supports cooperation between the Western Balkan countries in science, technology and innovation through the Steering Platform on Research and Innovation [10] [11].

The contribution to this platform is provided through the publication of announcements about events, research projects and relevant scientific documents, dissemination of information about funding opportunities, cooperation, awards, scholarships, etc. We can distribute our papers or notify about organization events that deal with topics that they are in our focus. These issues can be included in this platform, but first we must be registered and then we fulfill certain information (personalized information, networking opportunities), etc. [10] [11].

Since 2008 the WBC INCO.net ${ }^{24}$ has coordinated research policies of the Western Balkan countries and supports integration of these countries into the European Research Area. This platform is created by the European Commission under the $7^{\text {th }}$ Framework Program for Research and Technological Development (FP7). From 2008-2014 this project is hosted on the WBC-INCO.net and it is ${ }^{22}$ WBC-RTI.info is available at: https://wbc-rti.info/.

${ }^{23}$ The 7th Framework Program for Research and Technological Development is available at: https://ec.europa.eu/research/fp7/index en.cfm.

${ }^{24}$ The WBC INCO.net is available at: http://wbc-inco.net/index. 
supported by the Steering Platform on Research and Innovation for the WBC countries [10].

The WBC-INCO.net helps in the relationship development between the European Union and the Western Balkan countries in the field of science and technology. The Framework Program for Research, Technology and Development established by the European Commission is a strategic body designed to deal with Europeans (and Western Balkan countries) in multilateral and regional issues for science and technology policies.

WBC-INCO.NET consists of several basic objectives:

- It supports cooperation between the Western Balkan countries in science, technology and innovation through the Steering Platform on Research and Innovation.

- It identifies potential and priorities for research, technology and development and their inclusion transparently and methodologically in the FP7 and other EU programs.

- It helps to increase the researchers' participation from the region in the EU projects that they have mutual interest and benefit through the implementation of measures for capacity building and social activities (networked groups).

- It analyzes needs and obstacles to innovation for the WBC countries by exchanging best information and practices for innovation policies and it prepares a plan for further innovation cooperation.

- It creates closer cooperation between research and innovation, strengthening cross-sectoral dialogue and support stakeholder by training in innovation [10].

The European Union member states, candidate countries, countries that are part of the FP7 and the European Commission are members of this platform. Activities that they implement through this project are as follows:

- Defining the regional thematic priorities for science and technology.

- Analyzing opportunities for utilization and access in infrastructure, obstacles and cooperation models.

- It analyzes the policy needs and support for innovation. It identifies policies and measures them in order to improve the framework conditions for innovation and research.

- It organizes trainings, workshops, and learning groups in innovation and research for interested stakeholders.

- It organizes dialogue forums for innovation and it creates groups of experts in innovation for the Western Balkan countries.

- It supports National Contact Points and Research Information Systems. 29 partners, including the Ministries of Sciences and Technologies, agencies and analytic partners are the part of this consortium [10] [11].

Danube-INCO.net is a part of the WBC-INCO.net platform and focuses on providing research and innovation information for the Danube region. It is funded by the FP7 program and is officially supported by the EU's strategic ac- 
tions in the field of research and innovation in the Danube region. The focus of the Danube-INCO.net project is in two priority areas (PA): PA 7 "Knowledge Society" and PA 8 "Competitiveness" [10]. This project supports several aspects: political dialogue, analyze and support research and innovation activities and creates networks [11].

Together with 19 project partners and coordinating with the Center for Social Innovation (ZSI), this project tries to overcome the barriers that they hamper economic development in the Danube region. This project has provided events, publications and policy recommendations in relation to research and innovation cooperation in the Danube region, to reach the widest possible audience. It is engaged to enable the future macro-regional development for this region. The EU Strategy for the Danube Region includes EU member and non-member states with different economic systems, research and innovation [12].

The Danube-INCO.net project is built on its successor WBC-INCO.net coordinated by the Center for Social Innovation (ZSI) and it is completed in April 2014. Danube-INCO.net databases mainly contain news, funding opportunities and grants, calls for papers, jobs, events, projects, organizations, documents, etc., partially filled with notes from the WBC-INCO.net platform database. Therefore, we can say the Danube project also serves as an archive of knowledge developed by WBC-INCO.net [10] [12].

\subsection{NATO Science for Peace and Security Program}

Under the North Atlantic Treaty Organization (NATO) is created the Science for Pace and Security (SPS) Program through of which it is aimed cooperation between the NATO member countries and partner countries in terms of scientific research, technological innovation and knowledge exchange. This program provides funds, experts for advice and support for security activities in relevant areas that they are in line with the NATO's strategic objectives [13].

The SPS program provides opportunities for scientists, experts, alliance officials and partner countries to address the cyber-security issues and challenges in terms of defense, counterterrorism, or defense from chemical, biological, radiological and nuclear (CBRN) agents. It also supports the NATO missions and operations by caring for the development of advanced security technologies (sensors, detectors, nanotechnologies, etc.). This program also provides support for addressing human and social security aspects such as the implementation of United Nations Security Council Resolution 1325 on Women, Peace and Security (UNSCR 1325) [13].

The SPS program benefits incredibly from the expertise of agencies, divisions, delegations and similar actors, such as the Center of Excellence [13]. It is the international center of the military organization that it deals with training and education of leaders and specialists of the NATO members and partner states. The objective of this center is to assist in the doctrine development, learned lessons' elaboration, interoperability and skills improvement, testing and validation of concepts and results through experimentation [14]. 
This center provides expertise and experience that it has benefited from the alliance and supports its transformation [14]. The SPS program is created in 1958 and since this year it has been developed continuously. In 2013 the SPS program is reoriented and its focus is essentially focused on wide-scale strategic activities beyond scientific cooperation. It is funded by the NATO budget for civil issues and it supports cooperation through four grant mechanisms: "Multi-Year Research Projects, Advanced Research Workshops, Advanced Training Courses and Advanced Study Institutes" [13].

Applicants must make proposals that they are in harmony with one of the above mechanisms. Activities funded under the SPS Program should execute and respect the rules and regulations described in the SPS Program Management Handbook. The submitted applications must reach at least one of the key priorities and they have clear elements in terms of security. Applications approved under this program are evaluated according to scientific merits and security influences by the NATO experts, independent scientists and NATO countries [13].

Multi-year research \& development projects are projects under the SPS program. They extend from 2 - 3 years. Projects have been created to include more than one partner country and young scientist. The budget allocated for these projects is provided to cover cost of projects, scientific equipment, computers, software, training personnel during the project time and young scientists. Half budget is allocated for equipment, $20 \%$ for trainings and travel, and $15 \%$ for scholarships. These divisions may vary according to the needs of each project [15].

The SPS program also organizes training courses that extend for 7 days. Lecturers are international and they teach on advanced topics about security for civil science. These courses include pre-doctoral and postdoctoral students' audience with background on the training subject. Especially young scientists from the NATO partner countries have been encouraged to pursue such courses. The budget of an SPS grant is averaging 60,000 Euros and it is used for cost of organizing, traveling and training for more than 15 lectures. There participate $60-80$ students from partner countries admitted to funding from the NATO fund [15].

Under the SPS program funds, workshops are supported. They are held for 2 5 days as the Advanced Research Workshop (ARW). These workshops include 20 - 50 participants from the NATO partner countries. The budget allocated for the workshops is on average 30,000 - 40,000 Euros and it covers the ARW organizer payouts, students' travel and accommodation, participation of participants from the NATO and partner countries (if they cannot be financed from other sources) [15].

\subsection{Swiss National Science Foundation}

The Swiss National Science Foundation $(\mathrm{SNSF})^{25}$ is a financial organization supported by the Swiss Federal Government. The SNSF was created in 1952 by

${ }^{25}$ The Swiss National Science Foundation (SNSF) is also available at: https://en.wikipedia.org/wiki/Swiss National Science Foundation. 
physicist and Doctor Alexander von Muralt. The Foundation Council, the National Research Council and the Administrative Offices are three bodies that constitute the SNSF. The highest authority is considered the Foundation Council, which deals with strategic decisions. The National Research Council (NRC) is a body made up by prominent researchers where most of them work in the higher education institutions in Switzerland. Research proposals are sent to the SNSF and decisions are taken about their funding. They are evaluated by the NRC [16].

The NRC has over 100 members and it is divided into four divisions:

- "Division I: humanities and social sciences.

- Division II: mathematics, natural sciences and engineering sciences.

- Division III: biology and medicine.

- Division IV: programs (National Research Programs and National Centers of Competence in Research)" [16].

The above mentioned divisions work together with the local research commissions for review and implementation of financial schemes dedicated the higher education institutions. The local research commissions act as a link to the SNSF and they provide a local perspective for the applications that it derives from local institutions. Activities of the Foundation Council, the Research Council and the Research Commissions are supported and coordinated by the administrative offices. This office has tasked to control research fund's finances, requirements of external proposals and their assessment, to maintain national and international contacts in terms of research policies, the SNSF presentation into specific bodies and communication with public [17].

Through the SNSF funds support basic sciences in all academic disciplines. Based on the scientific criteria, the evaluation of researchers' proposals and selected funds for projects are made. The funds provided by SNSF are dedicated to research projects and research career. SNSF Professorships and Marie Heim-Vögtlin Grants (dedicated to promoting women's research) are some fellowships provided by the SNFS. Through these fellowships and grants, young researchers are also supported [17].

International collaborations with special programs, conferences and publications (especially dissertations) are supported by the SNSF. It consists of some important research programs such as the National Research Program (NRP) ${ }^{26}$ and the National Centers of Competence in Research (NCCR) ${ }^{27}$. The NRP is mandated by the Federal Council and this program provides funds for projects that generate knowledge and it has aimed to solve emergency problems. The projects under this program are up to 5 years and they are supported with a budget of $8-12$ million Swiss francs. The NCCR has aimed to strengthen the research in Switzerland. Each NCCR center is stationed in a higher education in-

${ }^{26}$ The National Research Program is available at:

http://www.snf.ch/SiteCollectionDocuments/snf-in-kuerze_en.pdf.

${ }^{27}$ The National Centers of Competence in Research:

http://www.snf.ch/SiteCollectionDocuments/snf-in-kuerze en.pdf. 
stitution and it has a competence center (a national and international participant). Funds with more than 20 million to 60 million Swiss francs have been allocated by the SNSF program, the university and third-party financiers for NCCRs (for 10 - 12 years) [16].

\subsection{National Science Foundation}

This independent agency was created in 1950 by the USA Congress. Its purpose is to promote the scientific advancement, to bring advancements in public health, prosperity and well-being, to provide national protection, etc. The National Science Foundation (NSF) supports research and people who make innovations and knowledge that transform the future. Through this support is given a boost to the USA economy, strengthened nation security and advanced knowledge. The NSF has an annual budget of $\$ 7.5$ billion and it funds $24 \%$ of all federal projects in terms of basic research in colleges and universities in USA. Its funds are allocated for research in mathematics, computer science and engineering and social sciences. Therefore, the NSF is considered as the main source of federal support [18] [19].

The NSF mission is to support basic science and engineering fields without medical sciences. It provides research funds for ideas in high risk and "high payoffs" fields, collaborations for innovative projects and projects that look like with fiction science but they can be realized. Research through the NSF funds is fully integrated with education, so the revolutionary work though supporting by these funds will be in the best of top scientists and engineer's training for the future. It holds constant contact with the research community to identify areas where research can be conducted by monitoring which areas most likely bring major breakthroughs and it selects merited people to conduct specific research [18].

The funding of science and engineering fields from the NSF is becoming through grants and collaboration's deals more than 2000 colleges and universities, scientific organizations and USA-based K-12 school systems. This foundation, in terms of federal support to academic research institutions, is counted as $1 / 4$ of the USA federal support. About 40,000 project proposals for research, education and training have been received by the NSF and nearly 11,000 of them are funded by it. The NSF foundation receives thousands application for graduate and postdoctoral scholarships. This agency does not have its own laboratories, but it is supported by the National Research Centers, universities and industries, international scientific organizations and engineering and other educational institutions for each academic level [18] [19].

Any time, scientists and engineers can submit their research and education proposal projects for current or emerging fields supported by NSF. The NSF receives more than 42,000 such proposal projects per year. They are evaluated strictly and according to the merits in order to achieve a fair and transparent evaluation. They are evaluated at least three independent reviewers (scientists, engineers or educators) who do not work and collaborate with NSF or any insti- 
tution that deals with the proposal of research projects. Analysts are selected by NSF in the rank of national experts in specific fields and their evaluation is confidential. Researchers decide which projects are in the high level and they achieve the "gold standards" of the scientific field. Then those are given the green light for funding by the NSF and they are placed in specific divisions in the respective fields [18].

The NSF's Division of Grants and Agreements office's analyzes recommendations of the relevant division and it sends them to an academic institution. This period extends 30 days after the office/program division has made a recommendation for the specific project proposal [18] [19]. The NSF consists of several major programs: "Education and Human Resources Program, Graduate Education Program, Research on Learning in Formal and Informal Settings Program, Undergraduate Education Program and Human Resources Development Program" [20]. Except of these programs, other programs are included by this foundation. The above mentioned programs mainly provide scholarships for students of different levels, research opportunities, research projects and young researchers support in basic fields, science and engineering [20].

\subsection{Fogarty International Center-Advancing Science for Global Health}

The Fogarty International Center (FIC) is an agency (organization) has purposed to advance and support global research through the National Institutes of Health (NIH) in the USA and international investigators through paternity with USA and international health care institutions. It has purpose to train the future scientists in order to detect and achieve the needs of global health. The FIC supports training, basic and clinical research for USA and international researchers in order further advance development of the world health. For almost 50 years, the FIC is considered a bridge between the NIH and the World Health Organization by enabling exchange investigators, training opportunities, research and similar initiatives in developing countries. During 50 years, FIC though its programs has provided training and research about 6000 scientists around the world [21].

Through its funds, it has funded over 500 projects by involving more than 100 USA universities. FIC gathers the best scientists to research and find the best ways for handling critical and global health problems such as polio eradication, pandemic diseases, and it helps strengthen the research capabilities in Africa. The FIC has provided the scientific training to local researchers and they can do brain scans, genetic analysis, and other sophisticated tests that are available from the clinical trial of a USA manufactured drug that it can help in treatment and stopping Alzheimer's disease in early stages [21].

The FIC as a vital part of NIH enables training of USA and neighbors' scientists and it builds research expertise to support institutions and other centers to carry out research on national and international implications. Through training, the FIC produces leaders who can formulate and enforce bioethics guidelines. It 
creates bodies that are capable of analyzing and evaluating research proposals and training others in terms of research ethics. More than 80\% (about $\$ 54$ million) of the FIC grants are awarded to the USA institutions for scholarships and other expenses. $80 \%$ of the FIC grants for 2016 are given to the USA institutions. $87 \%$ of the FIC's foreign funds in 2016 as grants have gone to the USA institutions. In 2016, 100\% of the FIC grants are earned by the USA researchers [21].

The FIC funds are offered to conduct research and train researchers in the various global health areas. The FIC and its partners in all NICs are working to build stable research staff in low and middle income countries [21]. This agency has a number of programs for research, training and innovation, such as: "Bioinformatics Research Training (H3Africa), Framework Innovations, African Association for Health Professions Education and Research, Health-Professional Education Partnership Initiative (HEPI), Medical Education Partnership Initiative (MEPI) Junior Faculty Research Training, Medical Education Partnership Initiative (MEPI), Fogarty HIV Research Training, AIDS International Training and Research (AITRP), International Research Collaboration (FIRCA)" [22].

This organization also has other programs for research, training and innovation: "Forgarty International Clinical Research Scholars and Fellows Program, Fogarty International Research Collaboration Award, Framework Programs for Global Health Signature Innovations Initiative, International Collaborative Genetics Research Training Program, Global Infectious Disease Research Training Program, Global Research Initiative Program for New Foreign Investigators, Health-Professional Education Partnership Initiative, International Clinical, Operational and Health Services Research and Training Award, International Implementation, Clinical, Operational and Health Services Research Training Award for AIDS and Tuberculosis, International Research Scientist Development Award, Independent Scientist in Global Health Award, Informatics Training for Global Health, International Training and Research in Environmental and Occupational Health, Japan Society for the Promotion of Science Fellowship Opportunities, Korean Biomedical Scientist Fellowship Program, Korean Visiting Scientist Training Award, Medical Education Partnership Initiative, Mobile Health: Technology and Outcomes in Low and Middle Income Countries, Global Research Training in Population Health and Women and Girls Health Administrative Grant Supplements" [22].

\subsection{Office of Naval Research}

The Office of Naval Research (ONR) is the executive agency under the USA Department of Defense and it is supported by the president's budget. The Chief of Naval Operations and the US Marine Secretary receive technical advice from the ONR. The Naval Research and Development Framework provides details on how the ONR directs research according to the framework's priorities, investment portfolio, and how it accelerates decision-making in order to overcome the business execution that enables the USA Naval Marine and its troops future operational concepts. It also offers technology support for the US Marine Corps. 
The senior leadership led by the Chief of Naval Research oversees investment portfolios for emerging technology and long-term research. The ONR Global has a mission to build relationships between the international scientific community and the Naval Research Enterprise (NRE). The purpose is to identify new technologies that they are necessary for the Naval Research and Development Framework [23].

The goals of the ORN Global have been pursued by following programs:

- The Visiting Scientists Program (VSP) ${ }^{28}$ is the ONR Program, which it aims to support international scholars for short-term research visits or international conferences in the USA, to collaborate and interact with researchers and to socialize with them for new ideas or finding in science and technology ( $\mathrm{S} \& \mathrm{~T}$ ) in cooperation with NRE. A reason for these research visits is to advance basic research through the collaboration of researchers and scientists.

- The Collaborate Science Program (CSP) $)^{29}$ enables international conferences, seminars and workshops with naval focus and they hold outside the USA.

- Research Grants ${ }^{30}$ offer grants to international scientists for research on the $S$ \& $\mathrm{T}$ marine. These grants support incorporation of innovation, science and international technology into the basic programs of the ONR and the NRE [23].

The ONR also consists of two educational programs: K12-Programs and Higher Education Program [24]. Under the K12 programs for the Science, Technology, Engineering and Mathematics, the ONR offers a $\$ 10$ million fund annually, where the individual funds reach to $\$ 200,000$ per year [25]. Under the Higher Education Program, the ONR offers three \$5,400,000 awards. Each individual can earn $\$ 600,000$ per year for 3 year period [26].

\subsection{Alexander Von Humboldt Foundation}

The collaboration between outstanding scientists and scholars is supported by the Alexander von Humboldt Foundation. It supports the mentioned groups inside and outside of Germany. This foundation enables interested people to go to Germany through fellowships and awards for research and work on a research project together with a collaborative partner.

Scientists from Germany can benefit from the foundation support for research projects outside country in one of the 28,000 alumni's of the Humboldt Foundation worldwide. This foundation is an intergovernmental organization for foreign cultural and educational policies in Germany and it promotes academic exchange and collaboration among the parties in research. We can become part of this foundation if we have excellent results and performance [27].

On this foundation have no quotes and special places for specific disciplines.

${ }^{28}$ The Visiting Scientists Program (VSP) is available at: https://www.onr.navy.mil/en/Science-Technology/ONR-Global/funding-opportunities.

${ }^{29}$ The Collaborate Science Program (CSP) is available at: https://www.onr.navy.mil/en/Science-Technology/ONR-Global/funding-opportunities. ${ }^{30}$ Research Grants are available at:

https://www.onr.navy.mil/en/Science-Technology/ONR-Global/funding-opportunities. 
The commissions consist of professionals and academics in all areas of specialization and they make independent decisions based on the applicants' academic results and performance. Regardless the effects of teamwork, the ability and dedication of the individual are considered decisive for academic success. The Humboldt Foundation offers scholarships for young researchers, experienced researchers and world authorities in specific disciplines. There is a host in the world for every branch of the Humboldt Foundation [27].

New researchers and collaborative partners can apply for research scholarships at the Humboldt Foundation, and they can stay in study periods at certain institutes. They can be encouraged by certain hosts to be nominated for research awards provided by this foundation. The scholarship includes compensation for research, research equipment, assistance, administrative, etc. The Humboldt Foundation is a foundation that functions under the civil law and it has a mission to promote science, research and intercultural understanding [27].

The German Federal Foreign Office, the German Federal Ministry for Economic Cooperation and Development, the German Federal Ministry of Environment, Nature Conservation and Nuclear Safety, and the National and International Financing Partners are the founders of the Humboldt Foundation. According to the statements made by the foundation, during 2016 it is estimated that the expenditures for the fulfillment of its mission were around $€ 116.2$ million, where $96 \%$ of funds and grants are enabled by the German Federal Government and the European Union (Figure 2) [27].

This foundation consists of various programs that are mainly dedicated to research in specific fields. It consists of many programs, but the most important are:

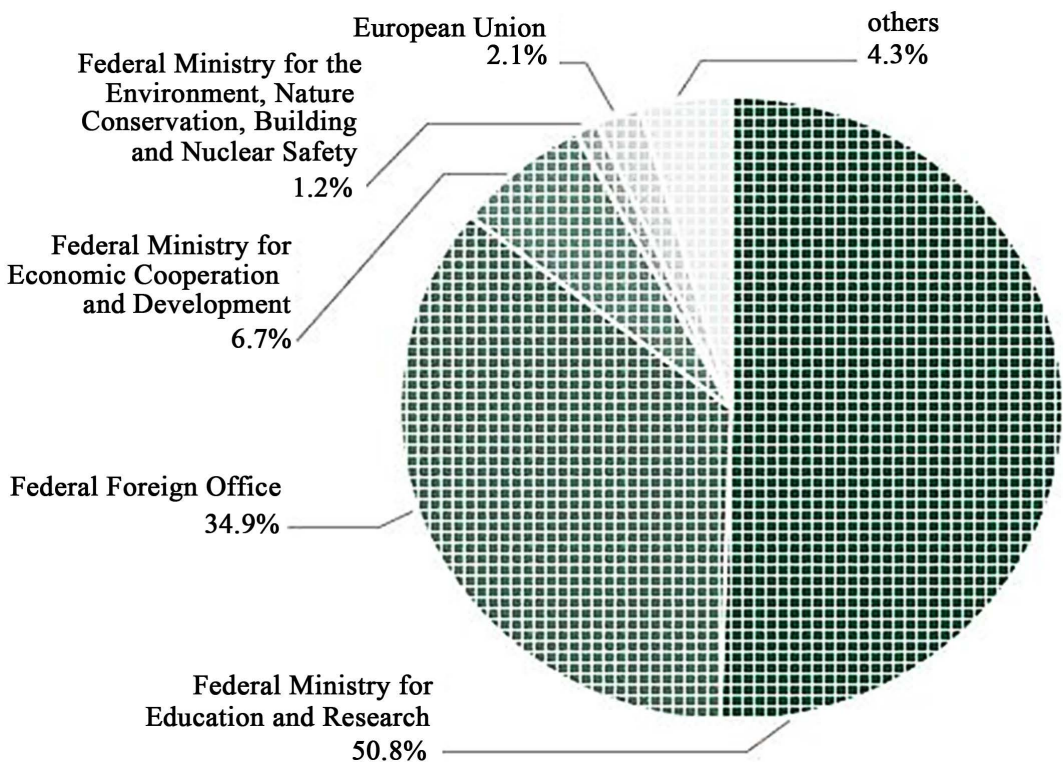

Figure 2. Funds of the Humboldt foundation enabled by national and international partners ${ }^{31}$.

${ }^{31}$ https://www.humboldt-foundation.de/web/partners.html. 
- "Alexander von Humboldt Professorship,

- Capes-Humboldt Research Fellowship for Brazilian Researchers,

- Feodor Lynen Research Fellowship,

- Frontier of Research Symposia,

- George Forster Research Fellowship,

- Humboldt Research Fellowship for Experienced Researchers,

- Humboldt Research Fellowship for Postdoctoral Researchers,

- JSPS Research Fellowship for Postdoctoral Researchers,

- Lynen Research Fellowship,

- Research Fellowship from the Japan Society for the Promotion of Science (JSPS),

- Research Fellowship from the Ministry of Science and Technology (MOST), Taiwan" [28].

\subsection{German Academic Exchange Service}

This service is known shortly as $\mathrm{DAAD}^{32}$ and it has a long tradition in support of cooperation between scholars and academia. In 1952, a student funded DAAD in Heidelberg. The DAAD is considered as one of the largest and most important foundation in the world for financing international students and researchers' exchange. Since it was founded until now, more than 1.9 million scholars in Germany and abroad has benefited from the DAAD funds. It is registered as an association and consists of the German higher education institutions and student bodies. Besides granting scholarships, DAAD deals with the internationalization of German universities, the promotion of German studies and German language abroad. It enables the best practices for university creation and advises decision-makers in the cultural, educational and development aspect for developing countries [30].

This service supports young people in gaining new opportunities, international academic and research experience in Germany and around the world. Master and doctoral students are the largest DAAD scholarship beneficiaries. Bachelor-level students have gained fewer scholarships and they have been particularly the best students of German schools abroad. The DAAD's budget for 2015 was 471 million Euros, while in 2016 it increased to 500, 3 million Euros [29].

This budget is also available through the support of the DAAD partners: the Federal Foreign Office (39\%), the Federal Ministry of Education and Research (23\%), the Federal Ministry for Economic Cooperation and Development (10\%) and the European Union (18\%). The DAAD's administrative budget is financed by the German Federal Foreign Office. The foreign scholars' costs are covered by the 16 countries of the Federal Republic of Germany because they have partnered with this service. Foreign governments, foundations, companies and the Stifterverbandfür die Deutsche Wissenschaft are also sponsors of DAAD [30].

Above 131,000 Germans and foreigners have been beneficiaries of the DAAD's funds and the EU supporting programs for academic and research is${ }^{32}$ Deutscher Akademischer Austauschdienst. 
sues.

Research infrastructure in Germany is recognized internationally because it offers potential assets for research in different disciplines. Through this service, funds are offered in various disciplines, facilities, a staff of experts, etc. These elements are in favor of young researchers to start their career and to fulfill research potential. This service provides opportunities for doctoral candidates and young researchers for research funds in various disciplines in Germany. It also provides funds for professorships, research group leaders, etc. The excellent scholarships are also offered for senior researchers in science, research and teaching [30].

DAAD offers funds (grants and scholarships) for undergraduate studies and research through these programs:

- "Undergraduate Scholarship,

- Study Scholarship for Graduating Seniors,

- German Studies Research Grant for Graduating Seniors,

- Research Grant for Graduating Seniors and

- Research Internships in Science and Engineering (RISE) Germany" [31].

This organization provides opportunities for graduates and research through these programs:

- "Research Grants,

- One-Year Grants (7 - 10 months),

o Cotutelle Doctoral Programs,

o Short-Term Research Grants,

o German Studies Research Grant.

- Study Scholarship,

- RISE (Research Internship in Science and Engineering) Professional,

- EMGIP (Émigré Memorial German Internship Program) -Bundestag Internship" [32].

DAAD also provides funds for PhD and Postdocs. The DAAD programs that enable scholarships for $\mathrm{PhD}$ and Postdocs studies and research are as follows:

- "Research Grants,

- Postdoctoral Researchers International Mobility Experience (P.R.I.M.E.)

- Humboldt Research Fellowships,

- Leo Baeck Institute-DAAD Fellowship,

- Leibniz-DAAD Fellowship Program,

- DLR (Deutsches ZentrumfürLuft-und Raumfahrt)-DAAD Research Fellowships,

- Summer Academy in Leipzig,

- RISE (Research Internship in Science and Engineering) Professional,

- RISE (Research Internship in Science and Engineering) Worldwide" [33].

The scholarships for faculties that are mainly dedicated to research, mobility and knowledge about German language are offered by DAAD. This service offers such scholarships through these programs:

- "Research Stays, 
- DAAD-AICGS (American Institute for Contemporary German Studies) Research Fellowship Program,

- DAAD Faculty Summer Seminar in German Studies,

- Conference Funding,

- Short-Term Lectureship,

- Visiting Professorship,

- Re-invitation Grant,

- Germany Today,

- DAAD Science Tour,

- Group Study Visit,

- RISE (Research Internship in Science and Engineering) Worldwide Learn German in Germany" [34].

DAAD also offers research awards such as:

- "Award (Scholarship) Winners,

- Sound Understanding” [35].

\subsection{German Research Foundation}

The German Research Foundation (GRF) ${ }^{33}$ is a German organization that provides research funds. It has a variety of grants, awards and research funds for science, engineering and humanities. The GRF is a self-governed organization with headquarters in Bonn and it is supported by the German states and the German Federal Government. Since 2017, nearly 100 researches in universities and other research institutions have been supported by this foundation. Research awards like the Gottfried Wilhelm Leibniz Prize and the Copernicus together with the Foundation for Polish Science are provided by the GRF [36] [37].

This foundation was created in 1937 as the German Association for the Support and Advancement of Scientific Research and it is known shortly as the German Research Foundation (GRF). After the World War II, this foundation was not active. In 1949 it was reactivated as a non-governmental organization, while in 1951 as the GRF. The purpose of the GRF is to fund the best research projects and projects of higher education institutions after they pass rigorous stages of evaluation of the research aspects [36]. In 2016 GRF has funded 31,000 research projects with a value nearly 3 billion Euros [37].

GRF consists of many programs for research, training, research infrastructure and excellence in research. Here will be mentioned only some of the most important programs for the aforementioned aspects. These programs are provided below:

- Research grants ${ }^{34}$,

- Research Training Groups ${ }^{35}$,

${ }^{33}$ The German Research Foundation is also available at:

https://en.wikipedia.org/wiki/Deutsche_Forschungsgemeinschaft.

${ }^{34}$ Research grants is available at:

http://www.dfg.de/en/research funding/programmes/individual/research grants/index.html.

${ }^{35}$ Research Training Groups is available at:

http://www.dfg.de/en/research_funding/programmes/coordinated_programmes/research_training groups/index.html. 
Table 1. Results about the European funds generated and classified by different indicators that are mentioned below in the table.

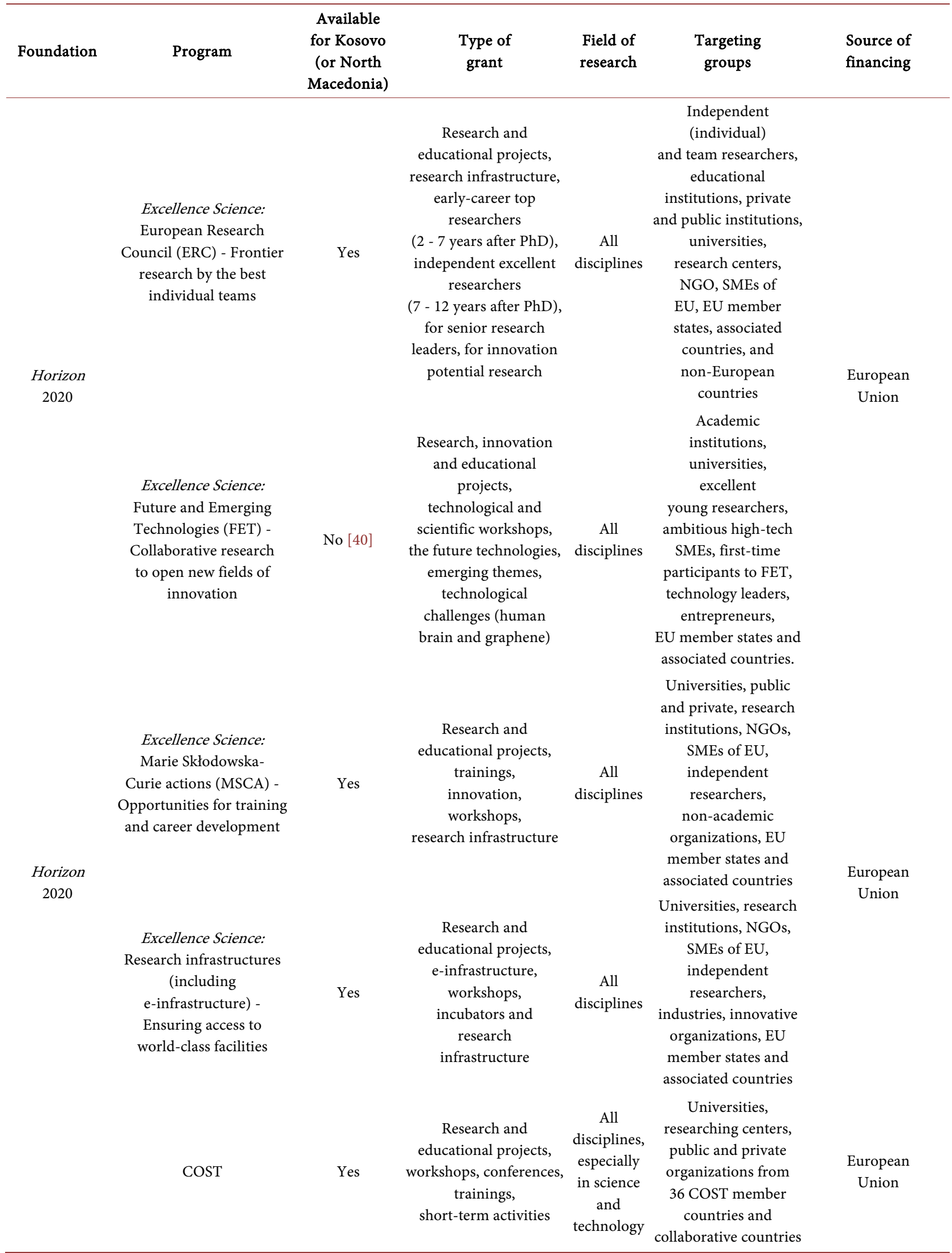




\begin{tabular}{|c|c|c|c|c|c|c|}
\hline \multirow[t]{3}{*}{ Erasmus + } & $\begin{array}{l}\text { Life Long Program } \\
\text { (higher education } \\
\text { and training) }\end{array}$ & Yes & $\begin{array}{c}\text { Research and } \\
\text { educational projects, } \\
\text { workshops, exchanges, } \\
\text { trainings, } \\
\text { study visits and } \\
\text { networking activities }\end{array}$ & $\begin{array}{c}\text { All } \\
\text { disciplines }\end{array}$ & $\begin{array}{l}\text { Universities, public } \\
\text { and private, } \\
\text { academic institutions, } \\
\text { think-tanks, } \\
\text { local authorities, } \\
\text { EU member states, } \\
\text { non-European } \\
\text { countries and partners }\end{array}$ & $\begin{array}{c}\text { European } \\
\text { Union }\end{array}$ \\
\hline & $\begin{array}{l}\text { Leonardo da Vinci } \\
\text { (vocational education } \\
\text { and training) }\end{array}$ & Yes & $\begin{array}{l}\text { Exchanges, trainings, } \\
\text { networking activities, } \\
\text { innovation and } \\
\text { educational projects, } \\
\text { transfer of innovation, } \\
\text { partnerships, } \\
\text { preparatory visits, } \\
\text { multilateral projects }\end{array}$ & $\begin{array}{c}\text { All } \\
\text { disciplines }\end{array}$ & $\begin{array}{c}\text { Universities, } \\
\text { public and private, } \\
\text { academic institutions, } \\
\text { think-tanks, local } \\
\text { authorities from } \\
\text { EU member states, } \\
\text { non-European } \\
\text { countries and partners }\end{array}$ & \\
\hline & $\begin{array}{c}\text { Comenius and } \\
\text { eTwinning (school } \\
\text { education, collaboration } \\
\text { and networking) }\end{array}$ & Yes & $\begin{array}{l}\text { Trainings, networking } \\
\text { activities, educational } \\
\text { projects, partnerships, } \\
\text { workshops, multilateral } \\
\text { collaborative projects }\end{array}$ & $\begin{array}{c}\text { All } \\
\text { disciplines }\end{array}$ & $\begin{array}{l}\text { Schools (institutions } \\
\text { providing general, } \\
\text { vocational and } \\
\text { technical } \\
\text { education - from } \\
\text { pre-school } \\
\text { education } \\
\text { to upper } \\
\text { secondary). } \\
\text { Teachers of any } \\
\text { subject area, } \\
\text { headmasters, } \\
\text { librarians and other } \\
\text { educational } \\
\text { staff (special need } \\
\text { teachers, ICT } \\
\text { coordinators) } \\
\text { from EU member } \\
\text { states, non-European } \\
\text { countries and partners }\end{array}$ & \\
\hline Erasmus + & $\begin{array}{c}\text { Grundtvig } \\
\text { (adult education) }\end{array}$ & Yes & $\begin{array}{l}\text { European co-operation } \\
\text { projects, learning } \\
\text { partnerships, } \\
\text { individual training } \\
\text { grants for adult } \\
\text { education, thematic } \\
\text { and network projects, } \\
\text { mobility } \\
\text { of individuals } \\
\text { (educational courses, } \\
\text { study visits, } \\
\text { assistantships), } \\
\text { multilateral projects, } \\
\text { preparatory visits }\end{array}$ & $\begin{array}{c}\text { All } \\
\text { disciplines }\end{array}$ & $\begin{array}{l}\text { Schools, universities, } \\
\text { adult education } \\
\text { establishments, } \\
\text { associations, } \\
\text { libraries, } \\
\text { museums, parents' } \\
\text { organizations, } \\
\text { research centers, } \\
\text { enterprises, } \\
\text { NGOs, non-profit } \\
\text { organizations, } \\
\text { voluntary } \\
\text { bodies, higher } \\
\text { education } \\
\text { institutions from EU } \\
\text { member states, } \\
\text { non-European } \\
\text { countries } \\
\text { and partners }\end{array}$ & $\begin{array}{c}\text { European } \\
\text { Union }\end{array}$ \\
\hline
\end{tabular}




\section{Continued}

Erasmus +

Youth in Action

Yes

Erasmus Mundus

Tempus

Yes

Erasmus +

Western

Balkan

Countries

WBC-RTI

Yes
Youth mobility project, youth exchange project, training/networking for youth workers project, volunteering projects, seminars, training courses, contact-making events disciplines and study visits, mobility of individuals (educational courses, study visits, assistantships), multilateral projects, preparatory visits

Research and Educational scholarships, study, teach, trainings, workshops, research infrastructure

Research and educational projects and scholarships, seminars, studies, teaching, trainings, workshops, research infrastructure, innovative activities All disciplines

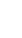
European NGOs;
international
governmental
non-profit
organization;
profit-making
organizations

(in the area of youth, sport and culture)

Universities, public

and private, research institutions, independent researchers, students, academic and administrative staff from all over the world

Universities, public and private, research institutions, independent All disciplines researchers, students, academic and

administrative staff from all over the world

Corporations, training centers, agencies, chambers,

development NGOs, SMEs, universities, non-profit organizations from European Union and Latin America

Research, science,

innovation and

technology projects, partnerships, scholarships, awards, research All disciplines infrastructure, trainings of researchers
European

Union

European

Union

European

Union

European Union and Latin

America

European Union and the

Austrian

Ministry

of Science,

Research

and

Economy 
Danube-INCO

\section{Western \\ Balkan \\ Countries}

$(W B C)$

NATO

Emerging

Security

Challenges

Division

Swiss
National
Science
Foundation
$(S N S F)$

Marie Heim-Vögtlin grants (dedicates women promotion

in research)
Research, science and

innovation projects,

partnerships,

scholarships,

Yes

awards, research

infrastructure,

trainings, workshops, experts in

innovation and science

Research, science and innovation projects, partnerships,

scholarships, awards, research infrastructure, trainings, workshops, experts in science

Scientific research projects, technological innovation and

knowledge exchange; young scientists; training courses; research infrastructure; workshops

Research and educational projects, pre-doctoral, doctoral and post-doctoral research and mobility, scientific exchanges, individual research projects, research partnership projects, research, conferences, career, workshops, trainings

Research and educational projects, assistant professorships, junior researchers, pre-doctoral, doctoral and post-doctoral researchers, individual research projects

Research and educational projects, doctoral and post-doctoral research and mobility, scientific exchanges, individual research projects, research partnership projects, research career, conferences
Research organizations, $\begin{array}{cc}\text { All } & \text { universities, } \\ \text { sciplines } & \text { SMEs, individual }\end{array}$ researchers and innovators

European Union

Research organizations, $\begin{array}{cc}\text { All } & \text { universities, } \\ \text { sciplines } & \text { SMEs, individual }\end{array}$ researchers and innovators

Young scientists, individual scientists, security experts, pre or post-doctoral students

of civil science and All technology, security policy-makers, disciplines think-tank, government, universities from NATO members and partner countries

NATO

Universities, young and individual researchers, scientific networks, doctoral and Swiss All

disciplines ostdoctoral students,

Federal Government junior researchers

Universities, young and individual researchers, pre-doctoral, doctoral and postdoctoral students,
junior researchers isciplines

ederal Government

Female scientists, young and individual

All
isciplines researchers, doctoral and Swiss postdoctoral students, Government junior researchers 


\section{Continued}

\section{Swiss \\ National \\ Science}

Foundation

(SNSF)
Ambizione

Yes

\author{
Alexander von \\ Humboldt \\ Professorship
}

Feodor Lynen

Research Fellowship

Yes

For research and education at universities and research institutions in Germany

All
disciplines

Frontiers of Research Symposia

No

Georg Forster

Research Fellowship

Yes

Alexander

von

Humboldt

Foundation and mobility, individual research projects, research partnership projects, research career education at universities and research institutions in Germany

All

disciplines All joint-research tri-national, conferences, science, humanities and technology

Long-term research, education, workshops, conferences

All disciplines
Research and

educational projects, doctoral and

post-doctoral research

For research and

Young professional, post docs, assistant professor, associate professor, scientific employment bi-national and$$
\text { (doctorate completed) }
$$

Humboldt Research Fellowship for Experienced Researchers
Yes full professor

Postdoctoral researchers, experienced researchers and junior researchers with several in

Outstanding young scholars, scientists,

$$
\begin{gathered}
\text { Postdoctoral and } \\
\text { experienced } \\
\text { researchers }
\end{gathered}
$$

Experienced

German Federal

Ministry of Education and

Research through the International

Research Fund for

Germany

The German

Federal Foreign

Office, the German

Federal Ministry of

Education and

Research, the

German Federal

Ministry of

Economic

Cooperation and

Development, the

German Federal

Ministry of the

Environment,

Nature Conservation and Nuclear Safety and national and international partners

German Federal

Ministry for

Economic

Cooperation and

Development

(BMZ)

German Federal researchers, assistant professors, junior research group leaders, Foreign Office and Federal Ministry of Education and Research 


\section{Continued}

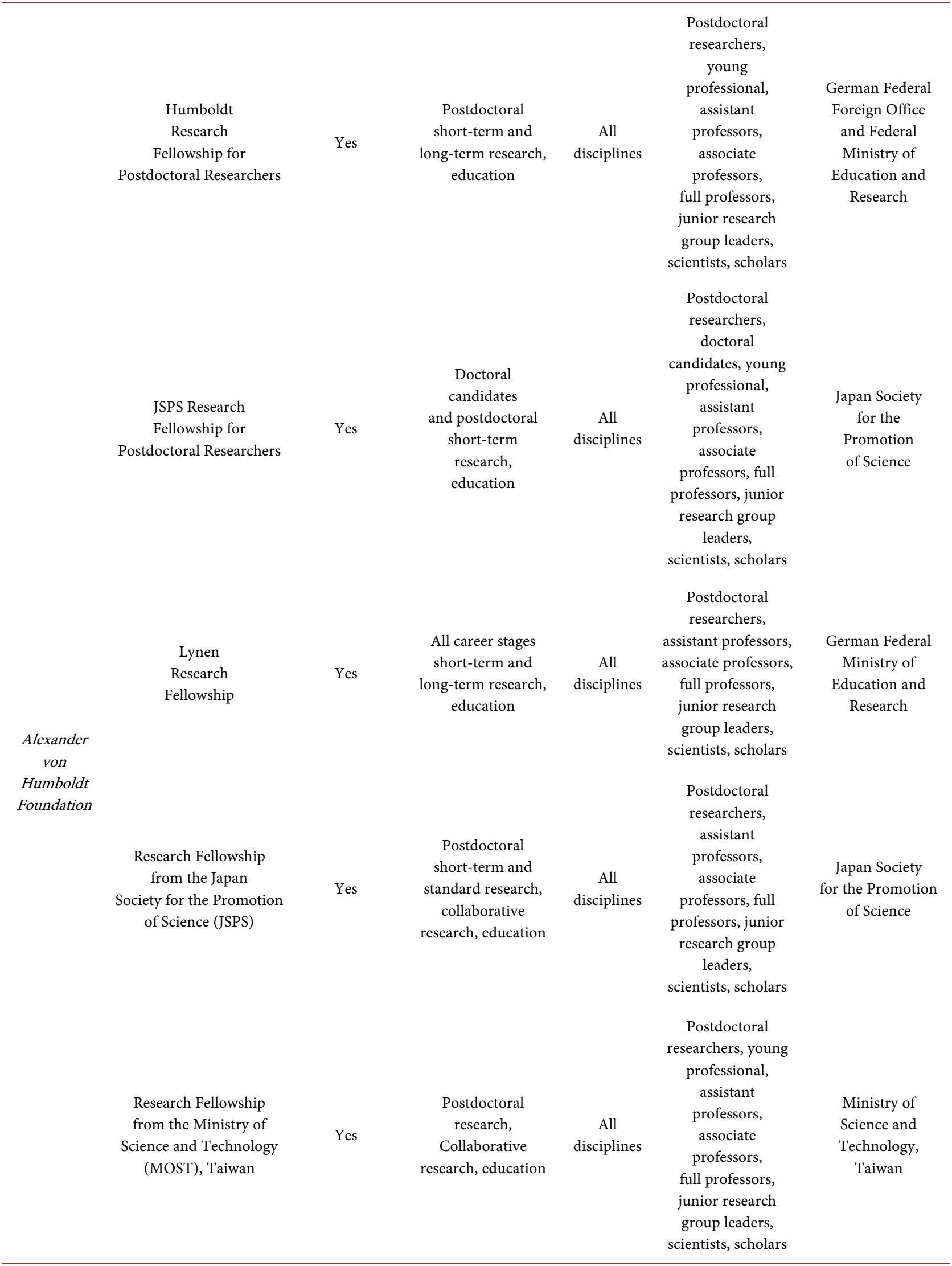




\section{Continued}

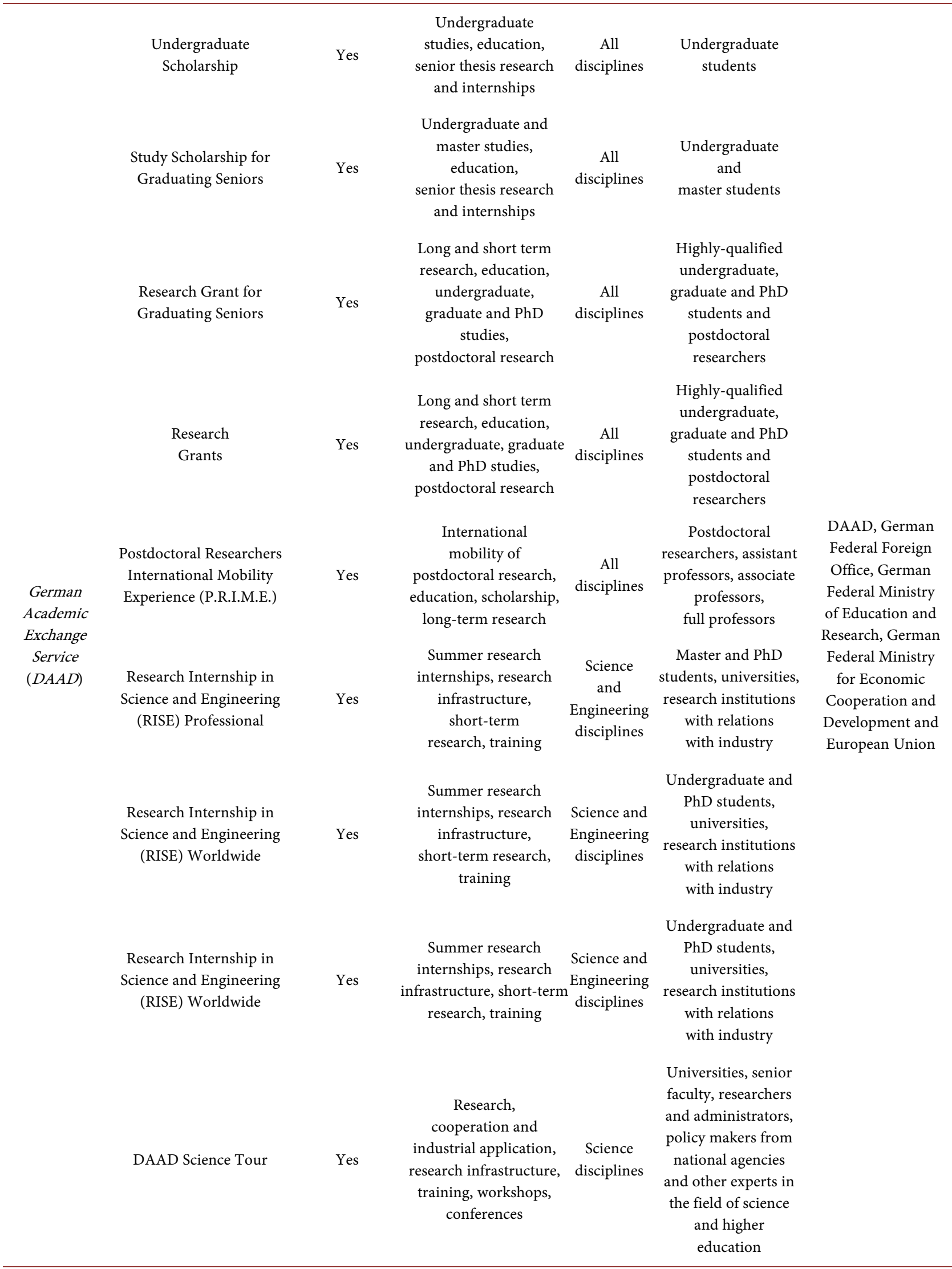




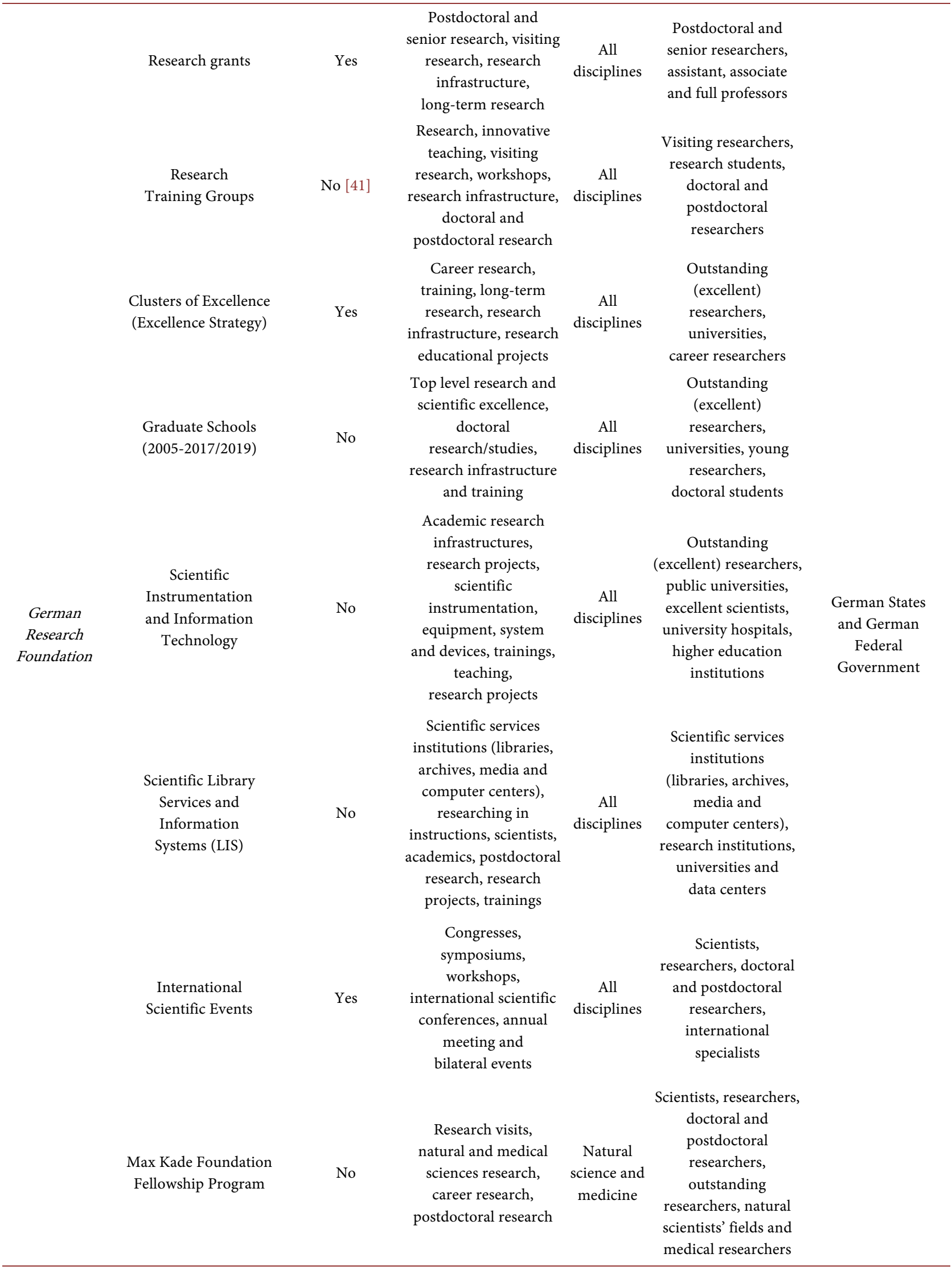


Table 2. Results about the USA funds generated and classified by different indicators that are mentioned below in the table.

\begin{tabular}{|c|c|c|c|c|c|c|}
\hline Foundation & Program & $\begin{array}{l}\text { Available for } \\
\text { Kosovo } \\
\text { (or North } \\
\text { Macedonia) }\end{array}$ & $\begin{array}{c}\text { Type of } \\
\text { grant }\end{array}$ & $\begin{array}{l}\text { Field of } \\
\text { research }\end{array}$ & $\begin{array}{l}\text { Targeting } \\
\text { groups }\end{array}$ & $\begin{array}{c}\text { Source } \\
\text { of financing }\end{array}$ \\
\hline & $\begin{array}{c}\text { Education and } \\
\text { Human } \\
\text { Resources } \\
\text { Program }\end{array}$ & No & $\begin{array}{l}\text { Research on learning, } \\
\text { facilitating the } \\
\text { translation of research } \\
\text { into practice, } \\
\text { supportive } \\
\text { learning } \\
\text { environments, } \\
\text { networking, } \\
\text { partnerships, } \\
\text { alliances } \\
\text { and collaborations }\end{array}$ & $\begin{array}{l}\text { Science, } \\
\text { technology, } \\
\text { engineering } \\
\text { and } \\
\text { mathematics } \\
\text { (STEM) } \\
\text { education }\end{array}$ & $\begin{array}{c}\text { Scientists, } \\
\text { technicians, } \\
\text { engineers, } \\
\text { mathematicians } \\
\text { and educators } \\
\text { (teachers) } \\
\text { that have access to } \\
\text { the ideas and tools } \\
\text { of science, } \\
\text { engineering and } \\
\text { education, } \\
\text { educational } \\
\text { institutions }\end{array}$ & $\begin{array}{c}\text { United State } \\
\text { of America } \\
\text { (USA) } \\
\text { government }\end{array}$ \\
\hline $\begin{array}{c}\text { National } \\
\text { Science } \\
\text { Foundation }\end{array}$ & $\begin{array}{l}\text { Graduate } \\
\text { Education } \\
\text { Program }\end{array}$ & No & $\begin{array}{c}\text { Fellowships, } \\
\text { innovative, science } \\
\text { and engineering } \\
\text { research and innovation, } \\
\text { professional careers, } \\
\text { traineeship: } \\
\text { research-based } \\
\text { master's and doctoral } \\
\text { degree programs } \\
\text { develop skills, } \\
\text { knowledge and } \\
\text { competencies, } \\
\text { scholarships in } \\
\text { cybersecurity, } \\
\text { research - related } \\
\text { careers and partnership } \\
\text { development }\end{array}$ & $\begin{array}{c}\text { Science, } \\
\text { technology, } \\
\text { engineering } \\
\text { And } \\
\text { mathematics } \\
\text { (STEM) } \\
\text { education } \\
\text { (fields) }\end{array}$ & $\begin{array}{l}\text { Graduate students, } \\
\text { minorities, persons } \\
\text { with disabilities, } \\
\text { veterans, master and } \\
\text { doctoral students, } \\
\text { scientists, engineers, } \\
\text { colleges, universities, } \\
\text { young researchers } \\
\text { and educational } \\
\text { institutions }\end{array}$ & $\begin{array}{c}\text { USA } \\
\text { government }\end{array}$ \\
\hline & $\begin{array}{l}\text { Research } \\
\text { on Learning in } \\
\text { Formal and } \\
\text { Informal } \\
\text { Settings } \\
\text { Program }\end{array}$ & No & $\begin{array}{c}\text { Innovative and } \\
\text { educational research } \\
\text { and practice, } \\
\text { development, } \\
\text { evaluation of learning } \\
\text { and teaching, } \\
\text { educational sciences } \\
\text { and technologies, } \\
\text { research and } \\
\text { learning } \\
\text { infrastructure, } \\
\text { human learning } \\
\text { in STEM; } \\
\text { learning in STEM } \\
\text { learning } \\
\text { environments, } \\
\text { STEM workforce } \\
\text { development, and } \\
\text { research on broadening } \\
\text { participation in STEM }\end{array}$ & $\begin{array}{l}\text { STEM } \\
\text { education } \\
\text { (fields) }\end{array}$ & $\begin{array}{c}\text { Scientists, } \\
\text { engineers, } \\
\text { educators, } \\
\text { innovators, } \\
\text { students, } \\
\text { individuals } \\
\text { of all ages and } \\
\text { backgrounds } \\
\text { through } \\
\text { self-directed } \\
\text { STEM learning } \\
\text { experiences, } \\
\text { teachers, independent } \\
\text { (individual) and } \\
\text { team researchers, } \\
\text { educational } \\
\text { institutions, private } \\
\text { and public } \\
\text { institutions, } \\
\text { universities }\end{array}$ & $\begin{array}{c}\text { USA } \\
\text { government }\end{array}$ \\
\hline
\end{tabular}




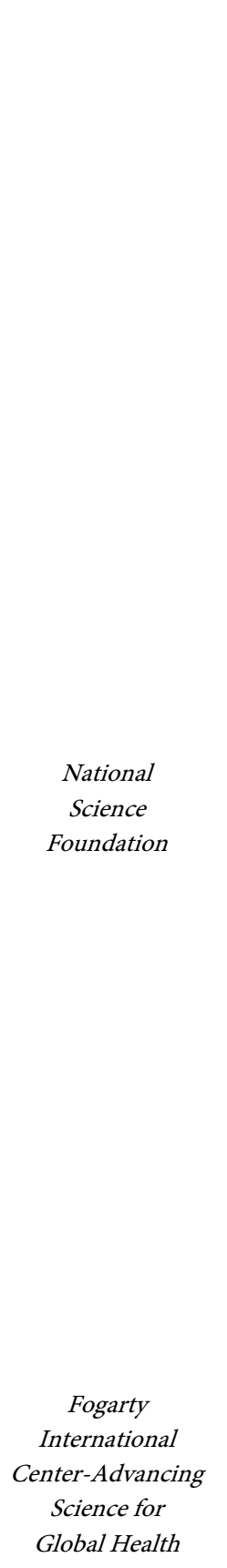

Undergraduate

Education

Program

Human

Resources

Development

Program
Educational innovation and research, research on learning, teaching and discipline-based research, research communities and research to evaluate and improve workforce initiatives

Educational innovation and research, excellence in education and research, knowledge, innovations, participation in the STEM enterprise, participation in STEM for use by stakeholders, to support and engage diverse populations in high quality STEM education and research programs, innovation and sustain competitiveness in the science and engineering enterprise

Bioinformatics research training for global health continent, genomics
Scientists, engineers, educators, innovators, students, individuals of all ages and backgrounds through self-directed

STEM

education

(fields) STEM learning
experiences, teachers, independent (individual) and team researchers, educational institutions, private and public institutions,

colleges, universities

\section{Scientists,} engineers, technologists, mathematicians, educators, innovators, individuals of all ages and backgrounds
STEM education (fields) through self-directed STEM learning experiences, teachers, independent (individual) and team researchers, educational institutions, private and public institutions,

colleges, universities

$\begin{array}{cc}\begin{array}{c}\text { Universities, } \\ \text { international }\end{array} & \text { USA } \\ \text { centers, scientists, } & \begin{array}{c}\text { government } \\ \text { data science }\end{array} \\ \text { researchers, } & \text { Department } \\ \text { researchers, } & \text { of Health and } \\ \text { educational } & \text { Human } \\ \text { institutions, } & \text { Services) } \\ \text { private and public } & \text { and } \\ \text { institutions, } & \text { international } \\ \text { colleges, } & \text { partnerships } \\ \text { Bioinformatics } & \text { (health } \\ \text { research } & \text { research } \\ \text { community } & \text { institutions) }\end{array}$

USA

government
USA

government
Interdisciplinary

(Bioinformatics and medicine)
Training

(H3Africa) research

for the African and health research

No

community 
A. Beshiri et al.

\section{Continued}

Health-Professional

Education

Partnership

Initiative (HEPI)

Medical

Education

Partnership

Initiative (MEPI)

Junior Faculty

Research

Training

Fogarty HIV

Research

Training
Education, trainings, research, partnerships and networks

Education, trainings, research, partnerships and networks

Research training and infrastructure, education, partnerships and networks

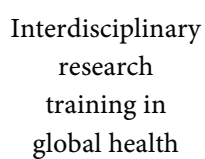

research
education in
health and
biomedicine

Interdisciplinary

research

education in

human health

\section{Universities, international centers, researchers, educational institutions, private and public institutions, colleges, individuals} internationa centers, independent researchers, educational institutions, private and public institutions, colleges, individuals

Research education and training

in human health (HIV)

\section{Health}

institution

and centers,

researchers,

health scientist,

individuals and
USA

government (The

Department of Health and

Human

Services)

and

international

partnerships

(health

research

institutions)

USA

government

(The

Department

of Health

and

Human

Services)

and

international

partnerships

(health

research

institutions)

USA

government

(The

Department

of Health

and

Human

Services)

and

international

partnerships

(health

research

institutions)

USA

government

(The

Department

clinicians of Health

and

Human

Services)

and

international

partnerships

(health

research

institutions) 
International

Research

Collaboration

The Visiting

Scientists

Program

The Collaborate

Science

Program

Office of

Naval

Research

Research

Grants

Yes

K12-Programs -

Science,

Technology,

Engineering and

Mathematics

Research, training,
partnership and
networks,
joint-research
training

Research, training, partnerships and networking, joint-research

Short-term research visits, conferences, workshops, joint-research
International naval conferences, seminars and workshops

Research, innovations, science and technology

Research, education, innovations, science and technology

USA

government

(The

Department

of Health

and Human

Services) and international partnerships

(health

research

institutions)

USA

government

(The

\section{Interdisciplinary \\ (dedicated to \\ research in \\ medical and health)}

Science and

Technology

Science and

Technology

Science and

Technology

Science and

Technology
Scientists,

researchers, individuals, health institution and centers
Department

of Health

and Human

Services) and international partnerships

(health

research

institutions)

Scientists, researchers, private and public universities, educational institutions and centers

Scientists, researchers, private and public universities, educational institutions and centers

Scientists, researchers, individuals, Department of Defense

(DoD) private and public universities, educational institutions and centers

Scientists, researchers, individuals, private and public universities, educational institutions and centers 


\begin{tabular}{|c|c|c|c|c|}
\hline $\begin{array}{l}\text { Higher } \\
\text { Education } \\
\text { Program }\end{array}$ & Yes & $\begin{array}{l}\text { Research, education, } \\
\text { innovations, } \\
\text { science and } \\
\text { technology }\end{array}$ & $\begin{array}{l}\text { Science and } \\
\text { Technology }\end{array}$ & $\begin{array}{c}\text { Scientists, } \\
\text { researchers, } \\
\text { individuals, } \\
\text { private and public } \\
\text { universities, } \\
\text { educational } \\
\text { institutions and } \\
\text { centers }\end{array}$ \\
\hline
\end{tabular}

- Clusters of Excellence (Excellence Strategy) ${ }^{36}$,

- Graduate Schools (2005-2017/2019) ${ }^{37}$,

- Scientific Instrumentation and Information Technology ${ }^{38}$,

- Scientific Library Services and Information Systems (LIS) ${ }^{39}$,

- International Scientific Events [38],

- Max Kade Foundation Fellowship Program [39].

\section{Results and Discussions}

Results about foundations and their programs are derived according to the different indicators and they are systematized in Table 1 and Table 2.

\section{Conclusion}

Different countries through their organizations provide funds for various purposes. These funds consist of special programs that are dedicated to education, research, innovation and researchers. In this paper, the details of these funding sources have been provided, including analysis of various funds and their programs for the above mentioned purposes. These funds are classified according to several indicators to see the various opportunities they offer through their programs. The results are given according to different indicators like availability for Kosovo and North Macedonia, type of grants, research area, target groups and financing, etc. Financial support through the programs of these funds is a great opportunity for the development of higher education and research all over the world, especially for young researchers with innovative and realizable ideas!

\section{Conflicts of Interest}

The authors declare no conflicts of interest regarding the publication of this paper.

${ }^{36}$ Clusters of Excellence (Excellence Strategy) is available at: http://www.dfg.de/en/research funding/programmes/excellence strategy/clusters excellence/index. $\underline{\mathrm{html}}$.

${ }^{37}$ Graduate Schools (2005-2017/2019) is available at:

http://www.dfg.de/en/research funding/programmes/excellence initiative/graduate schools/index. $\underline{\mathrm{html}}$.

${ }^{38}$ Scientific Instrumentation and Information Technology is available at: http://www.dfg.de/en/research_funding/programmes/infrastructure/scientific_instrumentation/inde x.html.

${ }^{39}$ Scientific Library Services and Information Systems (LIS) is available at: http://www.dfg.de/en/research funding/programmes/infrastructure/lis/index.html. 


\section{References}

[1] Liefner, I. (2003) Funding, Resource Allocation, and Performance in Higher Education Systems. Higher Education, 46, 469-489. https://doi.org/10.1023/A:1027381906977

[2] European Commission. What Is Horizon 2020? http://ec.europa.eu/programmes/horizon2020/en/what-horizon-2020

[3] Reillon, V. (2015) Overview of EU Funds for Research and Innovation. European Parliament, Brussels.

http://www.europarl.europa.eu/RegData/etudes/BRIE/2015/568327/EPRS BRI\%282 015\%29568327 EN.pdf

[4] European Commission Horizon (2020) Excellent Science. European Commission. http://ec.europa.eu/programmes/horizon2020/node/6

[5] Europlan UK. Europlan. http://europlan-uk.eu/eng

[6] South East Europe (SEE) - Transnational Cooperation Program. Program Presentation.

http://www.southeast-europe.net/en/about see/programme presentation/index

[7] COST. COST and Its Opportunities. http://www.cost.eu

[8] European Commission. What Is Erasmus +? http://ec.europa.eu/programmes/erasmus-plus/about en

[9] Czech Liaison Office for RDI (CZELO). Erasmus +. https://www.czelo.cz/en/other-programmes-and-initiatives/education-erasmus-plus ?CzlNewsItem page $=5$

[10] The Western Balkan Countries RTI. Western Balkan Countries Research, Technology, Innovation Information Platform. https://wbc-rti.info/about

[11] The Western Balkan Countries Platform. The Western Balkan Countries Platform Overview. http://wbc-inco.net

[12] Danube-INCO. NET. https://danube-inco.net/about/danubeinconet

[13] NATO. Science for Peace and Security Programme. https://www.nato.int/cps/ua/natohq/topics 85373.htm

[14] NATO. Centers of Excellence. https://www.nato.int/cps/en/natohq/topics 68372.htm

[15] NATO. What We Fund? Science for Peace and Security Grant Mechanisms. https://www.nato.int/cps/en/natolive/87260.htm

[16] Swiss National Science Foundation (SNSF). The Overview and Organization. http://www.snf.ch/en/theSNSF/organisation/Pages/default.aspx

[17] Swiss National Science Foundation (SNSF). Young Researchers. http://www.snf.ch/en/funding/directaccess/young-researchers/Pages/default.aspx

[18] National Science Foundation. About the National Science Foundation. https://www.nsf.gov/about

[19] National Science Foundation. About Funding. https://www.nsf.gov/funding/aboutfunding.jsp

[20] National Science Foundation. Programs: Directorate for Education and Human Resources (EHR). https://www.nsf.gov/funding/programs.jsp?org=EHR

[21] Fogarty International Center. The USA NIH. Fogarty's Role in Global Health. The Overview of Foundation. https://www.fic.nih.gov/About/Pages/role-global-health.aspx 
[22] Fogarty International Center. The USA NIH. Fogarty Programs. https://www.fic.nih.gov/Programs/Pages/default.aspx

[23] Office of Naval Research (ONR). ONR Global Funding Opportunities. https://www.onr.navy.mil/Science-Technology/ONR-Global/funding-opportunities

[24] Office of Naval Research (ONR). Education \& Outreach-Fostering a Healthy Scientist and Engineer Workforce for Tomorrow. https://www.onr.navy.mil/Education-Outreach

[25] Office of Naval Research (ONR). Founding Opportunities (1). https://www.onr.navy.mil/-/media/Files/Funding.../BAA/.../10-023-STEM-BAA.ash $\underline{x}$

[26] Office of Naval Research (ONR). Founding Opportunities (2). https://www.onr.navy.mil/-/media/Files/Funding.../BAA/.../N00014-18-S-F005.ashx

[27] Alexander von Humboldt Foundation. About the Foundation. https://www.humboldt-foundation.de/web/about-us.html

[28] Alexander von Humboldt Foundation. Alexander von Humboldt Foundation Programmes. https://www.humboldt-foundation.de/web/programmes.html

[29] DAAD. Budget and Funding Bodies. https://www.daad.de/der-daad/zahlen-und-fakten/en/30736-budget-and-funding-b odies

[30] DAAD. About DAAD Services. https://www.daad.org/en/about-us

[31] DAAD. Undergraduate Opportunities. https://www.daad.org/en/find-funding/undergraduate-opportunities

[32] DAAD. Graduate Opportunities. https://www.daad.org/en/find-funding/graduate-opportunities

[33] DAAD. PhD \& Postdocs. https://www.daad.org/en/find-funding/phd-postdocs

[34] DAAD. Opportunities for Research and Study (Faculty Programs). https://www.daad.org/en/find-funding/faculty

[35] DAAD. Award Recipients. https://www.daad.org/en/find-funding/award-recipients

[36] German Research Foundation (DFG). DFG in Profile-Mission Statement. http://www.dfg.de/en/dfg_profile/mission/index.html

[37] German Research Foundation (DFG). Annual Report, Activities and Results-Programmes and Projects. http://www.dfg.de/en/dfg profile/annual report

[38] DFG. International Scientific Events. http://www.dfg.de/en/research funding/programmes/international cooperation/int ernational events/index.html

[39] DFG. Max Kade Foundation Fellowship Program.

http://www.dfg.de/en/research funding/programmes/international cooperation/m ax kade/index.html

[40] Horizon 2020. Infographic of Country Map Participation. https://ec.europa.eu/programmes/horizon2020/en/system/files/newsroom/map jun e 2016 14124.jpg

[41] DFG. International Research Training Groups.

http://www.dfg.de/en/research funding/programmes/coordinated programmes/res earch training groups/international rtg/index.html 